\title{
PENGARUH PENAMBAHAN LIMBAH PLASTIK TERHADAP KUAT TEKAN MUTU BETON K-175
}

\author{
ASRI MULYADI ${ }^{1)}$, DIAWARMAN ${ }^{2)}$, DONNY ISMAIL ${ }^{3)}$ \\ Program Studi Teknik Sipil Fakultas Teknik Universitas Palembang \\ Jalan Dharmapala No.1A Bukit Besar Palembang 30139 \\ e-mail : asri_anang@yahoo.co.id ${ }^{1)}$,diawarman.unpal@gmail.com ${ }^{2)}$, donnyismail@yahoo.co.id ${ }^{3)}$
}

\begin{abstract}
ABSTRAK
Beton merupakan campuran yang bahan penyusunnya terdiri bahan semen hidrolik (portland cemen), agregat halus (pasir), agregat kasar (koral), air dan bahan tambahan (jika diperlukan). Bahanbahan limbah di sekitar lingkungan kita dapat dimanfaatkan sebagai bahan tambahan dalam campuran beton. Hal tersebut dapat memberikan alternatif untuk memanfaatkan limbah-limbah yang tidak terpakai, seperti limbah pecahan ember dan pecahan baskom plastik. Dengan optimalisasi pemakaian limbah plastik ini diharpakan mengurangi limbah yang mencemari lingkungan. Berdasarkan hal diatas, penulis mencoba melakukan penelitian pencampuran limbah plastik dengan semen, pasir, koral dan air dibuat dalam bentuk campuran beton. Mutu beton ditentukan oleh bahan dan campuran yang telah ditetapkan pada mutu beton K-175. Penelitian dan pengujian beton ini bertujuan untuk mengetahui kuat tekan beton dan memanfaatkan limbah plastik dan agregat halus (pasir) dari sungai musi, sedangkan agregat kasar (koral) dari lahat. Pada penelitian ini benda uji dicetak dengan menggunakan kubus baja ukuran $15 \mathrm{~cm} \times 15 \mathrm{~cm} \times 15 \mathrm{~cm}$ dan direndam, masing-masing umur perendaman yaitu 7 hari, 14 hari, 21 hari dan 28 hari dengan pengujian kuat tekan beton. Pada campuran beton K.175 tersebut dibuat campuran limbah plastik yang berfariasi yaitu dengan penambahan campuran limbah plastik 00 x $10^{-3}$ (normal), penambahan campuran limbah plastik $10 \times 10^{-3}$, penambahan campuran limbah plastik $20 \times 10^{-3}$ dan penambahan campuran limbah plastik $30 \times 10^{-3}$. Beton yang mencapai umur 28 hari karena pada umur ini menurut PBI 1974, kekuatan beton telah mencapai 100\%. Dari evaluasi hasil uji kuat tekan yaitu pada beton normal dengan umur 28 hari didapat kuat tekan beton sebesar 175,12,50 $\mathrm{kg} / \mathrm{cm}^{2}$, pada penambahan campuran limbah plastik $10 \times 10^{-3}$ dengan umur 28 hari didapat kuat tekan beton sebesar $172,10 \mathrm{~kg} / \mathrm{cm}^{2}$, pada penambahan campuran limbah plastik $20 \times 10^{-3}$ dengan umur 28 hari didapat kuat tekan beton sebesar $163,04 \mathrm{~kg} / \mathrm{cm}^{2}$ dan penambahan campuran limbah plastik $30 \mathrm{x}$ $10^{-3}$ dengan umur 28 hari didapat kuat tekan beton sebesar $158,51 \mathrm{~kg} / \mathrm{cm}^{2}$. Dari hasil evaluasi kuat tekan beton yang mengandung campuran limbah plastik $10 \times 10^{-3}, 20 \times 10^{-3}$ dan $30 \times 10^{-3}$ tidak mempunyai kuat tekan yang melebihi dari beton campuran limbah plastik $00 \times 10^{-3}$.
\end{abstract}

Kata Kunci : Kuat Tekan Beton, Agregat, Limbah Plastik.

\section{PENDAHULUAN}

\section{A. Latar Belakang}

Beton merupakan campuran antara semen portland, agregat, air dan terkadang ditambahi dengan variasi bahan tambah kimia sampai denganbahan tambah non-kimia pada perbandingan tertentu [1]. Bahan-bahan limbah di sekitar lingkungan kita dapat dimanfaatkan sebagai bahan tambahan dalam campuran beton. Hal tersebut dapat memberikan alternatif untuk memanfaatkan limbah-limbah yang tidak terpakai, seperti limbah pecahan ember plastik dan limbah pecahan baskom plastik. Dengan optimalisasi pemakaian limbah plastik ini diharpakan mengurangi limbah yang mencemari lingkungan.

\section{B. Tujuan Penelitian}

adalah :

Tujuan dilakukannya penelitian ini

1. Untuk mempelajari efektifitas penggunaan limbah plastik terhadap campuran beton, karakteristik beton, bahan pembentuk beton. 
2. Mengetahui pengaruh penambahan limbah plastik terhadap kuat tekan beton mutu beton K-175.

\section{Manfaat Penelitian}

Manfaat yang di peroleh dari penelitian ini diharapkan :

1. Dapat memberi informasi tentang pengaruh penambahan agregat limbah plastik terhadap kuat tekan beton.

2. Bagi masyarakat secara umum limbah plastik dapat dijadikan dan dimanfaatkan sebagai bahan agregat dan campuran komposisi bahan bangunan seperti beton.

\section{Rumusan Masalah}

Permasalahan utama yang dirumuskan dalam penelitian ini adalah bagaimana pengaruh penambahan limbah plastik terhadap kuat tekan mutu beton dengan variasi komposisi material adukan beton K-175.

\section{E. Batasan Masalah}

Dalam penelitian ini penulis membatasi ruang lingkup pekerjaan pengujian - pengujian bahan material dan benda uji kuat tekan di laboratorium. Penelitian dilakukan terhadap beton dengan membandingkan antara beton tanpa material tambahan dengan beton yang menggunakan material tambahan limbah plastik. perlakuan yang diambil pada penelitian ini sebanyak 4 perbandingan yaitu ;

1. Beton Normal.

2. Beton normal dengan material tambahan 10 x $10^{-3}$ limbah plastik.

3. Beton normal dengan material tambahan 20 x $10^{-3}$ limbah plastik.

4. Beton normal dengan material tambahan 30 x $10^{-3}$ limbah plastik.

Hasil pengujian dari ke empat variabel tersebut dibandingkan nilai kuat tekan dari masing-masing variabel benda uji tersebut sehingga didapatlah nilai kuat tekan yang paling kuat diantara variabel tersebut.

\section{TINJAUAN PUSTAKA}

\section{A. Beton}

Beton merupakan salah satu bahan konstruksi yang telah umum digunakan untuk bangunan gedung, jembatan, jalan, dan lainlain. Beton ini didapatkan dengan cara mencampur agregat halus (pasir), agregat kasar (kerikil), atau jenis agregat lain dan air, dengan semen portland atau semen hidrolik yang lain, kadang-kadang dengan bahan tambahan (additif) yang bersifat kimiawi ataupun fisikal pada perbandingan tertentu, sampai menjadi satu kesatuan yang homogen. Campuran tersebut akan mengeras seperti batuan. Pengerasan terjadi karena peristiwa reaksi kimia antara semen dengan air. Beton yang baik adalah beton yang kuat, tahan lama, kedap air, tahan aus, dan kembang susutnya kecil [1].

\section{B. Agregat}

Agregat merupakan butiran mineral alami atau buatan yang berfungsi sebagai bahan pengisi dari campuran beton. Agregat menempati $\pm 70 \%$ volume beton, sehingga sangat berpengaruh terhadap sifat ataupun kualitas beton, sehingga pemilihan agregat merupakan bagian yang sangat penting dalam pembuatan beton.

\section{Agregat Halus}

Agregat halus adalah agregat isi yang berupa pasir alam hasil disintegrasi alami dari batu-batuan (natural sand) atau berupa pasir buatan yang dihasilkan dari alat-alat pemecah batuan (artificial sand) dengan ukuran kecil $(0,15-5 \mathrm{~mm})$ [12]. Agregat halus yang baik harus bebas bahan organik, lempung, partikel yang lebih kecil dari saringan No.200, atau bahan-bahan lain yang dapat merusak beton.

\section{Agregat Kasar}

Agregat kasar ialah agregat dengan besar butiran lebih dari $5 \mathrm{~mm}$ atau agregat yang semua butirannya dapat tertahan di ayakan 4,75 mm (No.4 standart ASTM). Agregat kasar untuk beton dapat berupa kerikil sebagai hasil dari disintegrasi alami dari batubatuan atau berupa batu pecah yang diperoleh dari pemecahan manual atau mesin. Agregat kasar harus terdiri dari butir-butiran yang keras, permukaan yang kasar, dan kekal. Agregat harus memenuhi syarat kebersihan yaitu, tidak mengandung lumpur lebih dari 1 $\%$, dan tidak mengandung zat-zat organik yang dapat merusak beton [13].

\section{Semen Portlanda}

Semen portland ialah semen hidrolis yang dihasilkan dengan cara menghaluskan klinker yang terdiri dari silikat-silikat kalsium yang bersifat hidrolis dengan gips sebagai bahan tambahan [3]. Fungsi semen ialah untuk merekatkan butir-butir agregat agar terjadi 
suatu massa yang kompak atau padat, selain itu juga untuk mengisi rongga diantara butiranbutiran agregat.

\section{Air}

Air merupakan bahan dasar yang sangat penting dalam pembuatan beton. Air diperlukan untuk bereaksi dengan semen serta menjadi bahan pelumas antara butir-butir agregat sehingga mudah dipadatkan. Di dalam penggunaannya, air tidak boleh terlalu banyak karena akan menyebabkan menurunnya kekuatan beton itu sendiri. Air yang digunakan untuk pembuatan beton harus bersih dan tidak mengandung minyak, tidak mengandung alkali, garam-garaman, zat organis yang dapat merusak beton atau baja tulangan [4]. Selain itu, air juga digunakan untuk perawatan beton dengan cara pembasahan setelah dicor [14].

\section{E. Kuat Tekan (fc)}

Kuat tekan beton yang diisyaratkan fc adalah kuat tekan beton yang ditetapkan oleh perencana struktur (benda uji berbentuk kubus dengan ukuran $15 \mathrm{~cm} \times 15 \mathrm{~cm} \times 15 \mathrm{~cm}$ ), dipakai dalam perencanaan struktur beton, dinyatakan dalam Mega Paskal (Mpa) atau dinyatakan dalam Karakteristik $\left(\mathrm{Kg} / \mathrm{cm}^{2}\right)$.

\section{F. Faktor Air Semen}

Faktor air semen adalah perbandingan antara berat air yang digunakan dengan berat semen. Hubungan antara faktor air semen (f.a.s) dengan kuat tekan beton secara umum dapat ditulis dengan rumus yang diusulkan Duff Abrams (1919) dalam Samekto dan Rahmadiyanto (2001 : 43), sebagai berikut : $F c=\frac{A}{B} 1,5 X$

\section{METODOLOGI PENELITIAN}

Metode yang diterapkan dalam penelitian ini adalah metode eksperimen, yaitu penelitian yang bertujuan untuk menyelidiki hubungan sebab akibat antara satu sama lain dan membandingkan hasilnya. Pengujian yang dilakukan dalam penelitian ini adalah pengujian kuat tekan beton. Untuk semua pengujian yang dilakukan menggunakan standar-standar SK SNI. Adapun langkahlangkah metodologi yang akan dilaksanakan dalam penelitian ini adalah sebagai berikut.

\section{A. Persiapan Bahan Penelitian}

Penelitian ini dilaksanakan dilaboratorium uji bahan di Program Studi Teknik Sipil Fakultas Teknik Universitas Palembang, sebelum penelitian dilakukan perlu adanya persiapan bahan-bahan :

1) Semen Portland jenis I, merk Baturaja

2) Agregat halus, pasir Sungai Musi

3) Split/Batu Pecah, Split dari Lahat

4) Air yang dipakai dalam penelitian ini berasal dari instalasi air bersih yang ada di laboratorium Fakultas Teknik.

5) Limbah Plastik yang dipakai dalam penelitian ini diperoleh dari tempat pembuangan sampah yang berada di Kelurahan Bukit Baru Kecamatan Ilir Barat I Kota Palembang.

\section{B. Variabel Penelitian}

Variabel adalah segala sesuatu yang akan menjadi objek pengamatan penelitian. Variabel juga dapat diartikan sebagai faktorfaktor yang berperan penting dalam peristiwa atau gejala yang akan diteliti. Variabel dalam penelitian ini adalah dengan menggunakan berat semen $326 \mathrm{~kg} / \mathrm{m}^{3}$ dengan f.a.s 0,66 dan komposisi penambahan limbah plastik $\mathbf{0 x 1 0 ^ { - 3 }}$

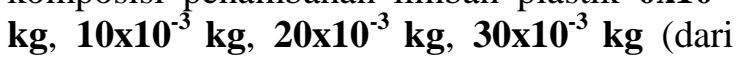
berat agregat semen).
C. Alat
1. Ayakan
2. Timbangan
3. Gelas Ukur
4. Kerucut Abrams
5. Penggaris/Meteran
6. Cetakan Beton
8. Batang Baja
9. Bak Air
10. Sendok Semen
11. Mesin Uji Tekan

\section{Prosedur Penelitian}

1. Tahap Pemeriksaan Bahan

Persiapan dan pemeriksaan bahan susun beton dilakukan di Laboratorium Fakultas Teknik Universitas Palembang. Bahan dan tahapan pemeriksaan meliputi :
a. Pemeriksaan Berat Jenis Pasir
b. Pemeriksaan gradasi pasir
c. Pemeriksaan kandungan lumpur pada pasir
d. Pemeriksaan berat jenis batu pecah (split)
e. Pemeriksaan gradasi batu pecah/split
f. Pemeriksaan semen 
g. Pemeriksaan air

2. Tahap Perencanaan Adukan

Metode Metode perencanaan campuran beton yang digunakan dalam penelitian ini dengan menggunakan campuran beton dengan mutu beton rencana fc' $14,5 \mathrm{MPa}$ (K.175). Dengan langkah kerja sebagai berikut:

1. Menentukan karakteristik kuat tekan yang disyaratkan diambil 14,5 $\mathrm{MPa}$ atau 175 $\mathrm{kg} / \mathrm{cm}^{2}$ pada umur 28 hari dengan jumlah cacat $5 \%$ dari banyak sample.

2. Menentukan deviasi standar (s) dengan melihat tabel.

3. Nilai tambah (margin) menggunakan rumus $=\mathrm{k} \times \mathrm{s}$.

4. Menghitung kekuatan rata-rata yang akan dicapai dengan menjumlahkan hasil nomor $1+3$.

5. Menetapkan jenis semen yang digunakan adalah semen Portland type I

6. Menetapkan jenis agregat yang dipakai adalah :

- Agregat halus : alami

- Agregat kasar : alam / batu pecah / split

7. Faktor air semen ditentukan dengan berpedoman pada grafik kemudian disesuaikan dengan type semen yang dipakai dan kekuatan tekan yang direncanakan pada umur 28 hari.

8. Faktor air semen maksimum dapat dilihat pada tabel yang disesuaikan dengan kondisi penggunaan beton tersebut.

9. Menentukan tinggi slump dengan menyesuaikan kegunaan dari beton tersebut untuk konstruksi.

10. Ukuran kadar agregat ditentukan dari hasil analisa saringan dengan mengambil ukuran agregat maksimum lolos saringan.

11. Kadar air bebas dapat dilihat pada tabel disesuaikan dengan besarnya slump dan ukuran agregat maksimum.

12. Kadar semen tiap $\mathrm{m}^{3}$ beton dihitung dari perbandingan air dengan faktor air semen (No. 11 / No.7 ).

13. Kadar semen maksimum tidak ditentukan jadi dapat diabaikan.

14. Kadar semen minimum ditetapkan 326 $\mathrm{kg} / \mathrm{m}^{3}$.

15. Susunan besar butir agregat disesuaikan dengan analisa saringan yang ditentukan.

16. Persentase agregat halus diperoleh dari perbandingan gabungan antara agregat halus dan kasar (lihat pada lampiran).

17. Berat jenis relatif agregat kering permukaan diperoleh dari perbandingan rata-rata berat jenis agregat halus dan kasar.

18. Berat jenis beton diperoleh dari grafik dengan jalan membuat grafik baru yang sesuai dengan nilai berat jenis gabungan.

19. Kadar agregat gabungan = berat jenis, beton dikurangi jumlah kadar semen dan kadar air.

20. Kadar agregat halus persentase agregat halus (No. 16) x kadar agregat gabungan (No. 19).

21. Kadar agregat kasar kadar agregat gabungan (No. 19) dikurangi kadar agregat halus (No. 20).

Dari langkah No.1 sampai No.21, didapat susunan campuran beton teoritis untuk tiap $1 \mathrm{~m}^{3}$ yaitu diperlukan semen sebanyak (No.2), air (No.11), pasir (No.20), koral (No.21).

Dalam perhitungan yang telah dilakukan, agregat halus dan agregat kasar dalam keadaan jenuh kering permukaan (SSD) maka apabila material yang ada dilapangan tidak jenuh kering permukaan harus dilakukan koreksi terhadap kebutuhan bahannya.

3. Tahap Pengadukan beton, Pemeriksaan Slump, dan Pembuatan Benda Uji

a. Pengadukan campuran beton

1. Agregat campuran dan semen diaduk merata dengan menggunakan mesin molen, sebelumnya memasukan air sekitar $80 \%$ dari yang dibutuhkan.

2. Selama pengadukan, sisa air dimasukan sedikit demi sedikit sampai airnya habis dalam waktu tidak kurang dari 3 menit.

3. Pengadukan dilakukan sebanyak satu kali untuk setiap macam campuran dan setiap pengadukan dilakukan pemeriksaan nilai slump.

b. Pemeriksaan slump

1. Masukkan adukan beton segar kedalam kerucut abrams dalam tiga lapis, masingmasing sepertiga dari tinggi kerucut.

2. Setiap lapis adukan ditusuk-tusuk dengan batang baja sebanyak 25 kali.

3. Setelah lapis beton terakhir selesai ditusuk, kemudian ditunggu selama 30 detik dan kerucut ditarik ke atas.

4. Nilai slump adalah selisih tinggi antara kerucut abrams dengan permukaan atas adukan beton setelah kerucut ditarik. 
5. Pengujian slump dilakukan sebanyak 2 kali untuk setiap pengadukan, kemudian hasilnya dirata-rata.

c. Pembuatan benda uji

1. Adukan beton dimasukkan dalam cetakan $15 \mathrm{~cm} \times 15 \mathrm{~cm} \times 15 \mathrm{~cm}$ yang sebelumnya telah diberi minyak pelumas pada bagian dalamnya.

2. Cetakan diisi dengan adukan beton sebanyak tiga lapis kemudian dipadatkan dengan cara ditusuk-tusuk dengan batang baja pemadat. Untuk setiap lapis adukan beton dilakukan sebanyak 25 kali tusukan secara merata sampai cetakan penuh.

3. Permukaan beton diratakan dengan batang baja sehingga permukaan atas adukan beton rata dengan bagian atas cetakan kemudian diberi tanda nomor dan tanggal.

d. Tahap Perawatan Benda Uji

Sehari setelah beton dicetak, kemudian cetakan dibuka, kemudian benda uji dimasukkan ke bak air yang telah tersedia di Laboratorium untuk direndam selama beberapa periode tertentu yaitu selama 7 hari, 14 hari, 21 hari dan 28 hari.

e. Tahap Pengujian Kuat Tekan Beton

Pengujian kuat tekan beton ini bertujuan untuk mengetahui kuat tekan beton yang dibuat apakah telah sesuai dengan yang telah direncanakan [6]. Peralatan yang digunakan adalah Timbangan dan Mesin Uji Kuat Tekan.

Langkah-langkah kerjanya adalah :

- Kubus beton yang di rendam atau di rawat setelah mencapai umur yang direncanakan maka beton tersebut diangkat dari perendaman. Kubus beton dikeringkan dari air kemudian ditimbang untuk mengetahui berat isi dari beton keras.

- Setelah itu dilakukan pengujian kuat tekan dengan menggunakan mesin uji kuat tekan.

- Pengujian kuat tekan dilakukan sampai beton tersebut tidak mampu lagi memikul beban yang diberikan oleh mesin penguji kuat tekan.

f. Analisis Data

1. Berat jenis pasir

2. Berat jenis batu pecah/split

3. Kandungan lumpur pada pasir

4. Kuat tekan beton

\section{ANALISIS DAN PEMBAHASAN}

A. Pemeriksaan Agregat Halus \& Kasar

Dari pemeriksaan yang telah dilakukan di laboratorium didapat data - data sebagai berikut :

1. Semen

Pemeriksaan secara visual menyimpulkan bahwa semen dalam keadaan baik yaitu berbutir halus, tidak terdapat gumpalan-gumpalan, sehingga semen dapat digunakan sebagai bahan susun beton. Semen yang digunakan adalah semen Baturaja dalam kemasan $50 \mathrm{~kg}$.

\section{Pasir}

Pasir berasal dari sungai musi

a. Bearat jenis pasir

Pasir Sungai Musi termasuk dalam agregat normal (berat jenisnya antara 2,5 2,7), sehingga dapat dipakai untuk beton normal dengan kuat tekan 15-40 MPa [9].

b. Kadar Lumpur

Pada pemeriksaan kali ini kadar lumpur yang didapatkan sebesar 1,3\%, Dengan demikian pasir Sungai Musi memenuhi syarat dan dapat digunakan sebagai bahan susun beton. Untuk pasir dengan kandungan lumpur yang lebih dari $5 \%$ atau melebihi dari peraturan SK-SNI-S-04-1989-F kadar lumpur maksimum pasir ialah 5\%, maka sebelum dipakai pasir tersebut hendaknya dicuci terlebih dahulu.

\section{Koral}

Pada kondisi kering didapat berat jenis Batu pecah/split Ex Lahat adalah 2,58 ton $/ \mathrm{m}^{3}$. Batu pecah/split Ex Lahat termasuk dalam agregat normal (berat jenisnya antara 2,5-2,7), sehingga dapat dipakai untuk beton normal dengan kuat tekan 15-40 MPa [9].

\section{Air}

Air harus bersih, tidak mengandung lumpur, minyak dan benda terapung lainnya yang dapat dilihat secara visual. Setelah dilakukan pengamatan secara visual terhadap air yang akan digunakan, menunjukkan sifatsifat antara lain tidak berwarna, tidak berbau, jernih (tidak mengandung lumpur), dan benda terapung lainnya sehingga air tersebut dianggap memenuhi syarat [17]. Pada penelitian ini air didapat dari instalasi air bersih di Laboratorium Fakultas Teknik 
Universitas Palembang yaitu Air PDAM Tirta Musi Palembang.

5. Daftar Isian (formulir) Perencanaan Campuran Beton

\begin{tabular}{|c|c|c|c|}
\hline No & Uraian & $\begin{array}{c}\text { Tabel / } \\
\text { Grafik } \\
\text { Perhitunga } \\
\mathrm{n}\end{array}$ & Nilai \\
\hline 1 & $\begin{array}{l}\text { Kuat tekan } \\
\text { yang } \\
\text { diisyaratkan }\end{array}$ & $\begin{array}{l}\text { Ditetapkan } \\
\text { Ayat 3.3.1 }\end{array}$ & $\begin{array}{l}14,5 \mathrm{MPa} \\
\text { pada } 28 \text { hari } \\
\text { bagian cacat } \\
5 \%\end{array}$ \\
\hline 2 & $\begin{array}{l}\text { Deviasi } \\
\text { Standar }\end{array}$ & Tabel 1 & $\begin{array}{l}7,5 \mathrm{~N} / \mathrm{mm}^{2} \\
\text { atau tanpa } \\
\text { data... N/mm }\end{array}$ \\
\hline 3 & $\begin{array}{l}\text { Nilai } \\
\text { Tambah } \\
\text { (margin) }\end{array}$ & $\begin{array}{l}\text { Ayat } 3.3 .2 \\
(1+3)\end{array}$ & $\begin{array}{l}(\mathrm{k}=1,64) \\
1,64 \times 7,5= \\
12,3 \mathrm{~N} / \mathrm{mm}^{2}\end{array}$ \\
\hline 4 & $\begin{array}{l}\text { Kekuatan } \\
\text { rata-rata } \\
\text { yang } \\
\text { ditargetkan }\end{array}$ & Ditetapkan & $\begin{array}{l}22,5+12,3 \\
=34,8 \mathrm{~N} / \\
\mathrm{mm}^{2}\end{array}$ \\
\hline 5 & Jenis semen & Ditetapkan & $\begin{array}{l}\text { Portland } \\
\text { Type I }\end{array}$ \\
\hline 6 & $\begin{array}{l}\text { Jenis } \\
\text { agregat : } \\
\text { kasar }\end{array}$ & & Batu Pecah \\
\hline & $\begin{array}{l}\text { Jenis } \\
\text { agregat: } \\
\text { halus }\end{array}$ & & Pasir \\
\hline 7 & $\begin{array}{l}\text { Faktor air } \\
\text { semen } \\
\text { bebas }\end{array}$ & $\begin{array}{l}\text { Tabel } 2 \\
\text { Grafik1/2 }\end{array}$ & $\begin{array}{l}0,56 \text { (ambil } \\
\text { nilai yang } \\
\text { terkecil) }\end{array}$ \\
\hline 8 & $\begin{array}{l}\text { Faktor air } \\
\text { semen } \\
\text { maksimum }\end{array}$ & $\begin{array}{l}\text { Ditetapkan } \\
\text { Ayat 3.3.3 }\end{array}$ & 0,66 \\
\hline 9 & Slump & $\begin{array}{l}\text { Ditetapkan } \\
\text { Ayat 3.3.4 }\end{array}$ & $\begin{array}{l}\text { Slump } 60- \\
100 \mathrm{~mm}\end{array}$ \\
\hline 10 & $\begin{array}{l}\text { Ukuran } \\
\text { agregat } \\
\text { maksimum }\end{array}$ & $\begin{array}{l}\text { Tabel } 6 \\
\text { Ayat 3.3.5 }\end{array}$ & $40 \mathrm{~mm}$ \\
\hline 11 & $\begin{array}{l}\text { Kadar air } \\
\text { bebas }\end{array}$ & Tabel 4 & $215 \mathrm{~kg} / \mathrm{m}^{3}$ \\
\hline 12 & $\begin{array}{l}\text { Jumlah } \\
\text { semen }\end{array}$ & 11:8 atau 7 & $\begin{array}{l}215: 0,66= \\
326 \mathrm{~kg} / \mathrm{m}^{3}\end{array}$ \\
\hline 13 & $\begin{array}{l}\text { Jumlah } \\
\text { semen } \\
\text { maksimum }\end{array}$ & Ditetapkan & $326 \mathrm{~kg} / \mathrm{m}^{3}$ \\
\hline 14 & $\begin{array}{l}\text { Jumlah } \\
\text { semen } \\
\text { minimum } \\
\end{array}$ & $\begin{array}{l}\text { Ditetapkan } \\
\text { Ayat3.3.2 }\end{array}$ & $275 \mathrm{~kg} / \mathrm{m}^{3}$ \\
\hline 15 & $\begin{array}{l}\text { Faktor air } \\
\text { semen yang } \\
\text { disesuaikan }\end{array}$ & Ditetapkan & \\
\hline
\end{tabular}

\begin{tabular}{|c|c|c|c|}
\hline 16 & $\begin{array}{l}\text { Susunan } \\
\text { besar butir } \\
\text { agregat } \\
\text { halus }\end{array}$ & $\begin{array}{l}\text { Grafik } 3 \\
\text { s/d } 6\end{array}$ & $\begin{array}{l}\text { Daerah } \\
\text { gradasi } \\
\text { susunan } \\
\text { butir IV }\end{array}$ \\
\hline 17 & $\begin{array}{l}\text { Persen } \\
\text { agregat } \\
\text { halus }\end{array}$ & & 36 persen \\
\hline 18 & $\begin{array}{l}\text { Berat jenis } \\
\text { relatif, } \\
\text { agregat } \\
\text { (kering } \\
\text { permukaan) }\end{array}$ & & 2,5512 \\
\hline 19 & $\begin{array}{l}\text { Berat jenis } \\
\text { beton }\end{array}$ & Grafik 13 & $2354 \mathrm{~kg} / \mathrm{m}^{3}$ \\
\hline 20 & $\begin{array}{l}\text { Kadar } \\
\text { agregat } \\
\text { gabungan }\end{array}$ & $\begin{array}{l}19-(12+ \\
11)\end{array}$ & $\begin{array}{l}2354-(326 \\
+215)= \\
1813 \mathrm{~kg} / \mathrm{m}^{3}\end{array}$ \\
\hline 21 & $\begin{array}{l}\text { Kadar } \\
\text { agregat } \\
\text { halus }\end{array}$ & $17 \times 20$ & $\begin{array}{l}36 \% \times 1813 \\
=652,68 \\
\mathrm{~kg} / \mathrm{m}^{3}\end{array}$ \\
\hline 22 & $\begin{array}{l}\text { Kadar } \\
\text { agregat } \\
\text { kasar }\end{array}$ & $20-21$ & $\begin{array}{l}1813- \\
652,68= \\
1.160,32 \\
\mathrm{~kg} / \mathrm{m}^{3}\end{array}$ \\
\hline
\end{tabular}

\section{B. Hasil pengujian slump beton}

\begin{tabular}{|c|c|c|}
\hline $\begin{array}{c}\text { Tanggal } \\
\text { cor }\end{array}$ & Beton & $\begin{array}{c}\text { Nilai } \\
\text { slump } \\
(\mathrm{cm})\end{array}$ \\
\hline $12-4-2018$ & Normal & 7,7 \\
\hline $13-4-2018$ & $\begin{array}{c}\text { Penambahan } \\
\text { limbah pecahan } \\
\text { plastik } 10 \times 10^{-3} \mathrm{~kg}\end{array}$ & 7 \\
\hline $14-4-2018$ & $\begin{array}{c}\text { Penambahan } \\
\text { limbah pecahan } \\
\text { plastik 10 x 10 } 0^{-3} \mathrm{~kg}\end{array}$ & 6,3 \\
\hline $15-4-2018$ & $\begin{array}{c}\text { Penambahan } \\
\text { limbah pecahan } \\
\text { plastik } 30 \times 10^{-3} \mathrm{~kg}\end{array}$ & 6 \\
\hline
\end{tabular}

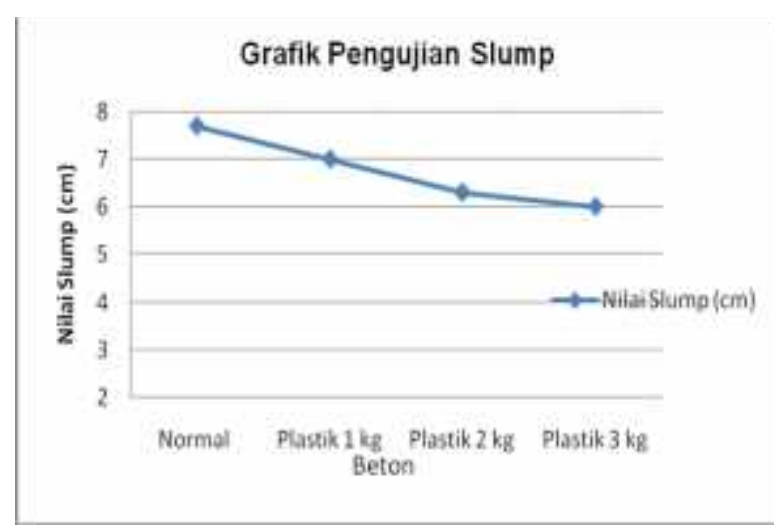

Berdasarkan grafik tersebut dapat diketahui bahwa slump yang dicapai mulai dari beton normal, beton dengan material limbah pecahan plastik sebagai bahan tambahan 
agregat kasar $10 \times 10^{-3}, 20 \times 10^{-3}, 30 \times 10^{-3}$ masih memenuhi slump yang disyaratkan antara $60-100 \mathrm{~mm}$.

\section{Hasil Pengujian Kuat Tekan}

Rekapitulasi Evaluasi Hasil Uji Kuat Tekan Beton dengan material limbah pecahan plastik sebagai bahan tambahan agregat kasar $10 \times 10^{-3}, 20 \times 10^{-3}, 30 \times 10^{-3}$ pada umur 7,14 , 21 dan 28 hari

\begin{tabular}{|c|c|c|c|c|}
\hline \multirow[b]{2}{*}{$\begin{array}{c}\text { Perlakuan } \\
\text { Beton } \\
\text { K.175 }\end{array}$} & \multicolumn{4}{|c|}{ Kuat Tekan $\left(\mathrm{Kg} / \mathrm{Cm}^{2}\right)$} \\
\hline & $\begin{array}{l}\text { Umur } \\
\text { Beton } \\
7 \text { Hari }\end{array}$ & $\begin{array}{l}\text { Umur } \\
\text { Beton } \\
14 \text { Hari }\end{array}$ & $\begin{array}{l}\text { Umur } \\
\text { Beton } \\
21 \text { Hari }\end{array}$ & $\begin{array}{l}\text { Umur } \\
\text { Beton } \\
28 \text { Hari }\end{array}$ \\
\hline $\begin{array}{l}\text { Beton } \\
\text { Normal }\end{array}$ & 129,83 & 152,47 & 168,47 & 175,12 \\
\hline $\begin{array}{l}\text { Penambaha } \\
\mathrm{n} \quad \text { limbah } \\
\text { pecahan } \\
\text { plastik } 10 \mathrm{x} \\
10^{-3} \mathrm{~kg}\end{array}$ & 122,28 & 140,40 & 151,72 & 172,10 \\
\hline $\begin{array}{l}\text { Penambaha } \\
\mathrm{n} \quad \text { limbah } \\
\text { pecahan } \\
\text { plastik } 10 \mathrm{x} \\
10^{-3} \mathrm{~kg}\end{array}$ & 126,81 & 137,38 & 144,92 & 167,04 \\
\hline $\begin{array}{l}\text { Material } \\
\text { Penambaha } \\
\mathrm{n} \quad \text { limbah } \\
\text { pecahan } \\
\text { plastik } 30 \mathrm{x} \\
10^{-3} \mathrm{~kg}\end{array}$ & 122,28 & 130,58 & 141,91 & 158,51 \\
\hline
\end{tabular}

Sumber : Hasil uji Laboratorium

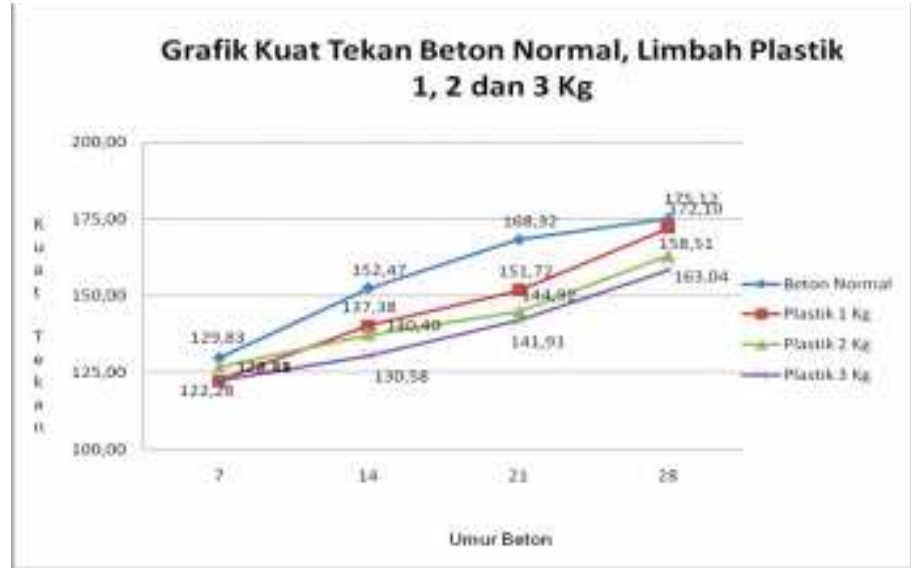

\section{KESIMPULAN}

Dari penelitian yang telah dilaksanakan dan dari hasil yang telah dicapai, penulis dapat menarik kesimpulan sebagai berikut :

1. Dari evaluasi hasil kuat tekan beton K.175 yang dihasilkan dari campuran tambahan limbah plastik sebanyak $00 \times 10^{-3}, 10 \times 10^{-}$ ${ }^{3}, 20 \times 10^{-3}$ dan $30 \times 10^{-3}$ adalah :

- Beton K.175 normal tanpa menggunakan campuran tambahan limbah plastik pada umur 28 hari didapat kuat tekan sebesar $175,12 \mathrm{~kg} / \mathrm{cm}^{2}$.

- Beton K.175 yang menggunakan campuran tambahan limbah plastik sebesar $10 \times 10^{-3}$ pada umur 28 hari didapat kuat tekan sebesar $172,10 \mathrm{~kg} / \mathrm{cm}^{2}$.

- Beton K.175 yang menggunakan campuran tambahan limbah plastik sebesar $20 \times 10^{-3}$ pada umur 28 hari didapat kuat tekan sebesar $163,04 \mathrm{~kg} / \mathrm{cm}^{2}$.

- Beton K.175 yang menggunakan campuran tambahan limbah plastik sebesar $30 \times 10^{-3}$ pada umur 28 hari didapat kuat tekan sebesar $158,51 \mathrm{~kg} / \mathrm{cm}^{2}$.

2. Dari hasil evaluasi kuat tekan yang didapat pada pengujian, beton yang mengandung campuran tambahan limbah plastik sebesar $00 \times 10^{-3}, 10 \times 10^{-3}, 20 \times 10^{-3}$ dan $30 \times 10^{-3}$ tidak mempunyai kuat tekan yang melebihi dari beton K.175.

\section{DAFTAR PUSTAKA}

[1] Tjokrodimulyo, K., 1992, “Teknologi Beton", Buku Ajar Pada Jurusan Teknik Sipil, Fakultas Teknik Sipil, Universitas Gajah Mada. Yogyakarta.

[2] Tjokrodimuljo, K., 2003, Teknologi Bahan Konstruksi, Buku Ajar. Jurusan Teknik Sipil, Universitas Atma Jaya. Yogyakarta.

[3] Persyaratan Umum Bahan Bangunan Di Indonesia (PUBI-1982) Direktorat Penyelidikan Masalah Bangunan.

[4] SNI 03-1970-2008 Cara Uji Berat Jenis dan penyerapan air agregat halus, Badan Standarisasi Nasional

[5] SNI 03 - 2834-2000 "Tata Cara Pembuatan Campuran Beton Normal" Badan Standarisasi nasional (BSN) ICS 91.100.30 
[6] SNI 03-1974-1990 Metode pengujian kuat tekan beton, badan standarisasi nasional (BSC) ICS 91.100.30

[7] Mulyono, T. 2003. Teknologi Beton. Andi: Yogyakarta.

[8] Bayu Krisfinanto : Metode Perawatan Beton (Curing), bayugembell.blogspot.co.id 2011.

[9] Tjokrodimulyo, K. 1996. Teknologi Beton. Nafiri: Yogyakarta.

[10] SNI 03-1968-1990 Metode Pengujian Analisa Saringan Agregat halus dan Kasar, Badan Standarisasi Nasional

[11] SNI 03-1972-1990 Metode Pengujian Slump Beton, Badan Standarisasi Nasional

[12] SNI 03-6820-2002 (2002:171),

[13] Persyaratan batu pecah yang digunakan dalam campuran beton (1982) Departemen Pekerjaan Umum.

[14] Tjokrodimulyo, K. 1996. Teknologi Beton. Nafiri: Yogyakarta.

[15] Dept. Pekerjaan Umum, Tata Cara Perhitungan Harga Satuan Pekerjaan Beton (SNI DT-91-0008-2007).

[16] Dipohusodo, I. 1999. Struktur Beton Bertulang Berdasarkan SK SNI-T-151991-03 Departemen Pekerjaan Umum RI. PT Gramedia Pustaka Utama : Jakarta.

[17] SK SNI-S-04-1989-F, "SPESIFIKASI BAHAN BANGUNAN BAGIAN A)

[18] Duff Abrams (1919) dalam Samekto dan Rahmadiyanto (2001 : 43) 